\title{
Mother of the Communion of the Incarnation
}

Mary is the Mother of the incarnate Son of God, who became a communion of divinity and humanity. Therefore, the mystery of Mary's motherhood refers to the Holy Trinity. As the beloved Daughter of the Father and the Bride of the Holy Spirit, Mary gave the Son of God His human nature. Through Her Son-Jesus Christ-She also became the Mother of the communion that exists between God and man.

Key words: Holy Trinity, Mary, Incarnation, Mother, communion.

"The superabundance" of that which was bestowed on Mary led Her to receive the graces of becoming the Mother of God and of experiencing a special and unique communion with every Person of the Holy Trinity. ${ }^{1}$ Without Mary, God's plan to enter into history would not have been realized-God would not have become Emmanuel (God with us), but rather only God in Himself and for Himself. The woman, who called Herself "lowly," meaning with child (see Lk 1:48), found Herself at the center of a profession of faith in the living God and could not be extricated from it. The Word became flesh, and the deepest meaning entered into the world. In order for this to happen, the Virgin, who would put Her entire person at God's disposal and become the place where God could abide in the world, was necessary.

Only after fulfilling this condition does the union between the Logos and the body really take place. [...] The 'world' to which the Son comes and the 'body' that He receives are not just anywhere or anything; this world and this body are a man and an open heart. Referring to a psalm, the Letter to the Hebrews interprets the Incarnation as a real interior

$1 \quad$ See C.S. Bartnik, Dogmatyka katolicka, vol. II, Lublin 2003, pg. 392. 
and divine dialogue: the Son says, 'a body you have prepared for me" to the Father. This preparation of a body takes place, however, through the fact that Mary says, 'Behold, I come to do your will' (Heb 10:5-7; Ps 40:6-8). The body was created for the Son because Mary completely entrusted herself to the Father's will and handed Her body over as a temple of the Holy Spirit."2

Number 722 of the Catechism of the Catholic Church (CCC) briefly states: "The Holy Spirit prepared Mary by his grace. It was fitting that the mother of him in whom 'the whole fullness of deity dwells bodily' should herself be "full of grace." Bartnik points out that theology has neglected the proper and essential-personal dimension of Mary's motherhood, which, after all, was not only a material and somatic act, but also one that She made with Her whole being. It is for this reason that Mary is also a spiritual and personal mother, and this is why we honor not only Her maternal body, "but also (and perhaps most importantly) Her person, Her personal reality."3

The Second Vatican Council teaches that "The Virgin Mary, who at the message of the angel received the Word of God in Her heart and in Her body and gave Life to the world, is acknowledged and honored as being truly the Mother of God and Mother of the Redeemer."4 The event of the Incarnation pertains, therefore, to both Christ and His mother-both are connected by the mysterious bond of motherhood

2 J. Ratzinger, "I za sprawa Ducha Świętego przyjąt ciato z Dziewicy Maryi”, in J.Ratzinger, H. von Balthasar, Maryja w tajemnicy Kościoła, trans. W. Szymona, Cracow 2007, pg. 73. "Regardless of its stage of development, the Descending Christology that the individual evangelists presented... was the true and proper theological basis that animated Mariology. Ascending Christology can ensure neither the true 'exalted' being nor the personal dignity and salvific significance of His Mother.' Interest in the person of Mary arises, therefore, out of interest in the person of Her Son, the Lord and Savior. [Theologians] speak about the Mother of God, who is 'full of grace'(Lk 1:28, 30) in order to better affirm Christ's divinity and saving role. Christology and its soteriological meaning are the context of faith with regard to Mary. Theologians speak of Mary in order to honor the Son, to profess His eternal origin, and pronounce His decisive greatness to people." (B. Forte, Maryja, Ikona Tajemnicy. Zarys mariologii symbolicznonarracyjnej, trans. B. Widła, Warsaw 1999, pg. 110).

3 C.S. Bartnik, Matka Boża, Lublin 2012, pg. 149. See also, pgs. 149n, 285. G. Greshake points out the problem of treating Mary's motherhood as a "fundamental principle" or "basic idea" of Mariology. He asks whether it would be better to speak of this idea as "the centering means" of Mary and Mariology (see Maria-Ecclesia. Perspektiven einer marianisch grundierten Theologie und Kirchenpraxis, Regensburg 2014, pg. 134n). See E. Adamiak, Traktat o Maryi, in Dogmatyka, (ed.) E. Adamiak, A. Czaja, J. Majewski, Warsaw 2006, pgs. 182-185. 
and sonship. ${ }^{5}$ Consequently, one cannot speak of Mary other than in reference to Her Son as well as the while economy of revelation and salvation that completely shone in Her. ${ }^{6}$ On the other hand, the intensity of the Mother-Son relationship makes it such that Mary reflects on the part of creation the fullness of that which takes place in Christ. This is why Her history is "[t]he history of the world in a nutshell, and the theology of this history spoken in one word." According to B. Forte, and in the words of S. de Fiores, Mary is "a living dogma, the truth of a fully-realized creation." "If the Son of Mary, who was born of Her in time, is the Son of God, born of the Father before all ages, then God, who reveals himself in the motherhood of the Virgin is the One Begotten and the Begetter, Son and Father. The Holy Spirit, who overshadowed Mary and brought about the miraculous and virginal conception of the Incarnate Word, shows that the union between the Father, who gave birth to the Son in eternity, and the Son, who was born in time and in eternity, is also their free openness to each other and to the Holy Spirit; it is the 'communion' and 'ecstasy' of God."

\section{The Communal Mystery of Motherhood in Reference to the Trinity}

The personal and deepest relationship possible-the communion between Mary and God-is the essence of Mary's divine motherhood that filled Her with grace and holiness and raised Her above all creation. ${ }^{9}$ B. Forte wrote that "all Marian dogmas have Christological and Trinitarian roots and converge on soteriological interest. [...] The Virgin Mother of God comes from the Holy Trinity, and the humble

$5 \quad$ See C.S. Bartnik, Matka Boża, pg. 147. "Der, den Maria geboren hat ist Gott, Gott der Sohn, Gottes Sohn. [...] Maria ist als Mutter des Mensch gewordenen Gottessohnes hineingenommen in das Mysterium der Erlösung und des endgültiges Heils" (G. Greshake, pg. 126n).

$6 \quad$ In his encyclical Redemptoris Mater (hereafter abbreviated as: RM), John Paul II writes: "If it is true, as the Council itself proclaims, that 'only in the mystery of the Incarnate Word does the mystery of man take on light,' then this principle must be applied in a very particular way to that exceptional 'daughter of the human race,' that extraordinary 'woman' who became the Mother of Christ. Only in the mystery of Christ is Her mystery fully made clear" (4).

See B. Forte, pg. 154.

Ibid, pg. 199n.

See R. Laurentin, Matka Pana. Traktat mariologiczny, trans. R. Siemieńska, Częstochowa 1989, pgs. 151-164. 
Servant of the Lord leads to the Holy Trinity. In Her God fulfills His covenant to do great things for us and for our salvation." 10

Mary's motherhood is "divine" primarily because She gave the Son of God His humanity - She conceived and gave birth to Jesus who became one and the same person: the Divine Word (Logos). ${ }^{11}$ This means

B. Forte, pg. 142. "Enfolded in the Father's plan, Mary is overshadowed by the Spirit, who makes Her the Mother of the Eternal Son in human form. The Annunciation manifests the Holy Trinity as a womb that is worthy to be praised-a womb that Mary receives and in which, at the same time, She is the womb of God. In this way, a completely unique and profound relationship is established between Mary and the Holy Trinity. 'Mary is redeemed in a loftier way due to the merits of Her Son. United with Him through a close and idissoluble bond, She is given the greatest gift and the most profound dignity - namely, to be the Mother of the Son of God and, through this role, the most loved daughter of the Father and the holy dwelling place of the Holy Spirit.' Mary is the 'temple and resting place of the Holy Trinity." She is an icon or image of the Holy Spirit.'The Virgin is the place where the Holy Spirit is made present, while the Child is the place where the Word is made present: both constitute the image of the Father's mysterious image which is conveyed in the human language of images.' The individual aspects of the Virgin-Mother-Bride can be referred to the three Divine Persons. As a Virgin, Mary stands before the Father purely receptive and ready to take Him in. For this reason, She is an etneral icon. She is receptivity, acceptance, and consent to be loved by Her Incarnate Son, who came from the Silence. As the Mother of the Incarnate Word, Mary is close to him in the gratuitousness of the gift as a source of life-giving love. She is, therefore, the maternal icon of the One who always and forever initiated and began love and Who is the pure source, giving itself, the Bearer, the first Source, eternal Loving Father. As the Ark of the Spousal Covenant between heaven and earth, the Bride, in which the Eternal unites to himself the history and fullness of the unexpected novelty of Her gift, Mary remains part of the unity of the Father and Son and the unity between them and the world, which is why She is as an icon of the Holy Spirit who it is the eternal spouse, the bond of infinite love, and the mysetery of God's constant openness to human history. In the Virgin Mother, the humble servant of the Almighty, the very mystery of the divine relationship is thus reflected: in the unity of Her person She reflects the life of God in Three Persons." (Ibid, pg. 160n).

"In the tradition of the faith, the terms 'Mother of God' and 'God's Mother' are practically interchangeable: if the former is more personal and relational and involves the entire realm of the relations and references that exist between Mother and Son, then the latter is more technical and is, from a strictly theological point of view, more precise. The latter conveys that Mary gave birth to the Son of God. The broader and more personal meaning not only excludes the more precise meaning, it also includes it and is based on it. This title confirms the Virgin's absolute uniqueness; She is given the unique and miraculous experience of bearing in Her body the Creator of life. It also describes Mary in such a clear way that Elizabeth is amazed at the miraculous sign and calls Her, according to St. Luke (1:43), 'the Mother of my Lord.' For this reason, from of old the Church has expressed its faith in this mystery in prayer by addressing Mary with the title: 'We fly to thy protection, O holy Mother of God [...].' The 
that the person of Jesus of Nazareth was realized not in Himself, but in the Divine person of the Word. Therefore, the ultimate living subject is one and the same. The Son of God is also Her Son-Her real and not adopted Son according to His humanity, but not according to His divine nature. There are not "two sons" in Christ, and His humanity and divinity do not in any way cease. Hence, Mary-as the Mother of God-is unique and unrepeatable. As such, She gives us a unique opportunity to change the world in Christ. ${ }^{12}$

Mary's motherhood most perfectly and ineffably participates in the fatherhood of God..$^{13}$ In God, fatherhood is also motherhood. Therefore, although human language is very limited in expressing the supreme mystery of the Father, one can say that Mary, as the Mother of God, is the greatest icon of God as Father-Mother. ${ }^{14}$

Mary's motherhood was made possible through the Holy Spirit, whose power created not only Jesus' body in the womb of Mary, but also the Mother and Her human and divine motherhood. The Holy Spirit formed Mary personally, spiritually, and existentially above all in relation to the Father and the Son. He sanctified Her; bestowed on Her His unfathomable personal world; surrounded Her with glory and light; made the full communion between Mother and Son possible; permitted Her to participate in the mission of Her Son and the Holy Spirit in the world;

center and heart of the mystery revealed in Mary are united in Her being the Mother of the Eternal Son, who became human for us" (Ibid, pg. 194n).

R. Laurentin, pg. 147: "Her motherhood is similar to eternal paternity in the fact that it is the fruit of a spiritual and holy act-in this instance, an act of faith. This similarity is far advanced. When reflecting on the mystery of Trinitarian origin, two concepts must be considered: the conception of the Word (by analogy with an act of human reason), and the birth of the Son. Similarly, in the Incarnation, Mary spiritually conceives by faith and physically bears in Her body. However, the comparison should not be exagerated; the analogy is very distant here. While the conceptual dualism (the act of reason - the act of conceiving) depends exclusively on our way of thinking about the Holy Trinity, it is real when it comes to Mary. Through our two complementary ways of thinking, we arrive at the one act of the Father, who conceives or bears the Son. Mary, on the other hand, performs two different acts, although they are essentially compatible and united: one in Her mind, and the other in Her body. The most striking point of this analogy is not the act of conception, but that which results from it. The eternal begetting and conception in time concern the Son Himself: the Son of the Father and the Son of Mary are not two Sons, but one and the same Son: the Second Person of the Holy Trinity. This is the fundamental similarity that governs all others; it draws the divine motherhood like a mysterious satellite into the orbit of God's fatherhood." 
and enabled Her to enter into full communion with all humankind. ${ }^{15}$ For this reason, Mary's motherhood is both social and redemptive. ${ }^{16}$

\section{Mother of the Communion of Jesus Christ's Humanity and Divinity}

A communion of natures existed in Christ. ${ }^{17}$ S. C. Bartnik calls Mary "Mother of the entire Christ" 18 and emphasizes Her relationship to the One who was created as a man, entered into history, and "connate" in the person of the Son of God because of Her. "Eve prepared the "genesis of Mary,' while Mary prepared the "genesis of Christ." ${ }^{19}$ Mary was the one who introduced man into the life of God on earth, giving Christ a fourfold maternal gift: humanity, historicity, society, and a unique role in salvation history. ${ }^{20}$ "Desiring to become a true and complete person with a body, soul, and human self, and out of love for humanity, the Word of God could not not be 'born of a Woman' (Gal 4:4), meaning conceived with a body, biology, and material human self in the very interior of humanity and born of a real mother, from a human nature, and ultimately 'with a human personality."'21 "A 'salvific environment

$15 \quad$ See C.S. Bartnik, Matka Boża, pg. 157; R. Laurentin, pgs. 147-150.

16 See R. Laurentin, pgs. 166n.

See M. Jagodziński, Węzłowe zagadnienia chrystologii komunijnej, Radom 2013, pgs. 149-229.

Ibid, pg. 108.

See Ibid, pg. 36.

Ibid, pg. 37. Bartnik explains: "Christian anthropology does not have good theories that [respond to] questions regarding what a person-woman (and man) bears: if it is only 'a living body,' or 'biological nature' itself, or perhaps in some kind of way the psyche and the soul of a person, or perhaps ultimately 'the person.' We know, however, that man, who is conceived and born, is not only some kind of material and animated 'product' of biological organisms, but in some kind of sense-as personalism emphasizes—he comes from the "persons of his parents,'even though he comes through their body. In this way, the body is as if a "sign" of man, and the 'person' is the meaning of man. Therefore, the mother surely transmits something more than just the material embryo, the body, and its vital abilitys only. As the concrete medium of human nature, the mother subconsciously and paramountly bears the whole person: flesh from flesh, soul from soul, self from self, even though every person exceeds himself and the results exceed their individual cause. However, we do not know how humanity is generally transmitted to concrete individuals [... We know that] human nature was transmitted to the Son of God through a person-Mary, which consequently means that Christ was bound to human history, to the biotic 
arose within the person of Mary, and in this environment the personal union between the Word of God and Jesus took place..."22

The oldest Mariological text in the New Testament is a passage from St. Paul's Letter to the Galatians 4:4-5: "But when the fullness of time had come, God sent his Son, born of a woman, born under the law to ransom those under the law, so that we might receive adoption." This text is neither completely historical, nor purely biographical (since it lacks names). Rather, it is historico-redemptive in a more theological sense. At the basis of this text is the fully developed incarnational truth. St. Paul identifies the Messiah with the Son of God and connects His birth with the history of salvation. God sent His Son, who already existed in heaven out of love for man, to became a man born of a virgin. His birth and entire earthly life was His kenosis. Because of this, the Son did not cease to be God-he did not "turn into" a man. The text very strongly emphasizes the identity of God and man, which has been called "personal" throughout the ages. "She who gave birth to the Son of God is proof that the divine plan and the Messiah, who lived on the earth - and to whom She gave our blood (Heb. 2:14), and the identity of the Son of God and the Son of Man exist."23

The Gospel passages about Christ's childhood (Mt 1-2 and Lk 1-2)24 as well as the Mariology in St. John's Gospel (1:1-14) confirm the pronouncement in Galatians 4:4. The prologue of John's Gospel contains all of the basic themes: Jesus' pre-existence, His coming from the Father into His own as the light of the world, His virginal birth, His humanity, and His glory as the Only Begotten Son of God. The basic Christian thought: "The Word became flesh and dwelt among us..." (John 1:14) contains this Marian aspect: "The Word of God became flesh from Mary's flesh, meaning Mary made the Son of God 'human' and brought the Son of God into history, a family, Israel, the world, and even life and death." 25

Bartnik discusses the theories that explain Mary's human and divine motherhood - the motherhood of the communion of the divinity and

and abiotic world, and to the entire universe. Consequently, Mary's womb is a mystery that lies at the center of history, of the earth, nature, and the universe. But the decisive subject was Mary's person: Her self, Her mind, Her will, and Her action, thanks to which She introduced the Fruit of Her womb (Lk. 11:27) into all structure and and laws of universal reality." (Ibid). See Ibid, pg. 300n.

Ibid, pg. 39.

Ibid, pg. 62n.

See Ibid, pgs. 68-94.

Ibid, pgs. 94. 
humanity in Jesus Christ. The theory that is based on Christological modalism emphasizes that everything in Christ's humanity must be subordinate to His Divine Person as the proper subject. Bartnik approaches this theory critically and notes that it aligns with CCC 486: "today, the majority of theologians accept Jesus' human 'I.' In antiquity, the self was not considered and the person himself was treated as an unnamed substance or as a 'mass of being.' Today it is very ironic to teach that Jesus was 'completely and truly a man who coexisted with us' (the first four Councils of the Church), and that He simply did not have a human self or (at least) psychological subjectivity. Jesus' humanity would be rational (i.e. it would be a pure thing, even Jesus' soul would also be considered a 'thing.' In this case, Mary would be either the Mother of the 'thing' or the Mother of His divine nature, in which the 'human thing' is subjected." ${ }^{26}$ Bartnik fantasizes that Mary simultaneously gave birth to God and man in the same sense and on the same ontological plane (God-man" or "Man-god"). Therefore, calling Mary 'Anthropotokos' or 'Christotokos' would be to separate Jesus Christ into 'two' and destroy the Mother of God. Referring to W. Granat, Bartnik states that this theory is absurd. ${ }^{27}$

The theory based on the thought of the Council of Chalcedon (451) and St. Leo the Great ( $† 461)$, which was adopted in the West, stated that the created Mother can beget simply and directly only the human nature. Hence, Jesus Christ was born twice-first in the womb of the Father as God, and then in the womb of Mary as Man. Both births cannot be equated with each other, but Jesus Christ was simultaneously and completely God and Man (His divinity and humanity existed in one and the same hypostatic person)—the divine hypostasis received into Himself the human nature-therefore, Mary indirectly and secondarily gave birth (realistically and really, not metaphorically) to "God according to the flesh" - the Son of God (the person of the Son of God, adds Bartnik), One of the Three (Persons of the Trinity). ${ }^{28}$ The fruit of

$26 \quad$ Ibid, pgs. 159 . Bartnik adds: "in modalist theory, humanity and divinity are identical, thereby belittling the Chalcedonian truth that they 'are not confused' in Jesus Christ and that 'the distinct natures did not disappear when they were united in Jesus Christ.'[...] The Chalcedonion truth asserts that divinity and humanity are two modes (modus) in which the Word of God appears, and even that Jesus Christ is a third type of being 'God-man' or 'Man-god,' where there is no distinction between what is divine and that what is human. One and the same person would appear one time as man, then a second time as God." (Ibid.). See Ibid, pg. 159n.

"The Father reveals himself in Mary's motherhood as the One who has loved selflessly for centuries and who, therefore, is always present where all true, 
Mary's womb (see Lk 1:42) is, therefore, the ontological subject of the Second Person of the Holy Trinity. Bartnik adds that limiting the title

unselfish, and fruitful love is born in time. Finally, the Holy Spirit, who is sent from the Father and overshadows the Virgin and makes Her the Mother of God, reveals Himself in the virginal motherhood in two ways that recall the depth of His divine mystery. On the one hand, the Holy Spirit connects eternal and temporal births, fusing together the Bearer with the Begotton in time and in eternity ( $\mathrm{He}$ is the vinculum caritatis aeterne!), and, on the other hand, by the virtue of this same bond that occurs through His overshadowing, the Holy Spirit unites the eternal source of the life of love-the Father-with the receptivity of the Incarnate Word, and, in it, all of human history. As the bond of love that exists between the Father and Son, the Holy Spirit reveals Himself as their personal way to leave themselves; in the case of the Word, He takes on human nature so that it can participate in its own acceptance and receive the Father's love. As God's issue from himself, the Holy Spirit is a gift of God for the world just as He was the gift of the Father for the Virgin Mary, so that She could give birth to the eternal Son in time. In this way, the depth of the mystery of the Trinitarian God is revealed in the event of the virginal motherhood of Mary. This love gives itself in human history: it is the events of the eternal beginning of love, the flowing source of time and eternity and the ultimate end of everything that happens in the world-the Father; the events of eternal origin and the coming in time ('duplex nativitas') of the pure act of receiving eternal Love in dialogue with the Divine Persons, who-in the Incarnation-make it possible for people to receive this same love-the Son. Finally, the events of the continual "happening" of God, the still new flow of love between the Father and the Son and, at the same time, their being open to the created object of their uncreated love: the Holy Spirit-the One from whom God issues in order to enter into history, while history leaves itself in order to enter into God. Thanks to the event that is expressed in the title "Mother of God,"one perceives that the "essence of the living God is His love in His eternal self-abasement as Love and accepting himself has a loved Love, He returns to Himself and to the infinite openness to the other in freedom as the Spirit of trinitarian love. The essence of the Christian God is live in its eternal process; it is the trinitarian history of love; it is the Holy Trinity as the eternal story of love that awakens, embraces, and permeats the history of the world - the object of its pure love.' It is precisely this reflection on the Trinity in the event of a fully human, although divine in origin and fruitfulness, motherhood that makes it possible to perceive that the bond between time and eternity, which was established by the Incarnation, is similar to that bond that is realized in the motherly womb between the one Conceived and His Mother. In other words, because She became the 'womb' of the Son of God through grace, Mary testifies that God in the Holy Trinity is the 'womb' of the world that, like Her, is immersed in the darkness of faith through the relationship of the miraculous and transcendent love of the Holy Trinity. In this way, in Her astonishment at the mystery, the Mother of God refers to the Holy Mother of the world, the Holy Trinity-the God who is thrice holy, from whom, in whom, and through whom every thing exists. The Holy Trinity appears in Mary, the Mother of God, and became Man for us and for our salvation, as our holy Mother, who is worthy of praise, in the creative mystery of redemptive love." (B. Forte, pg. 201n). 
of the Mother of God to the humanity itself threatens Christ's divinity and His hypostatic union, and it deprives Mary of Her relationship to the Second Divine Person. From this, it follows that the title Theotokos is praiseworthy and true, even though it will never be possible to fully and adequately explain this mystery. ${ }^{29}$

The modern theory of the economy of salvation deals not so much with Mary's relationship to God in His eternal transcendence, but with the history of salvation as the Bible presents the truth about the birth of the Savior on earth in one and the same salvific phenomenon. The term "Theotokos" is the most appropriate and legitimate because, by giving birth to Christ, Mary became the "Holy Niche" in which the Trinitarian salvific economy was realized-the action of the "Trinity of the economy of salvation." Thus, the Virgin Mary can be found within the salvific action of the Holy Trinity who descended to the earth in the Person of Christ. God appeared historically only in the Son of Mary, and She is the "receptacle" of the presence of the Eternal God made flesh (see J 1:14; Phil 2:6n). Through Mary, God became like creation, which is material and exists in time, history, social life, and culture, and the Holy Trinity became "economical" or "historico-redemptive." Mary is the mystery of the real relationship with the Holy Trinity. God, who reveals Himself in Mary, is the one who bears and who is born; whereas the Holy Spirit, who "came upon" Mary created the union between the Father and Son as well as the union between Mary and the Son and, through this, the Son's union with all of humanity. Trinitarian Love (F. Courth) came into the world through Mary, such that She has become the greatest icon of this redemptive Love. ${ }^{30}$

Bartnik also points out the current theory in Mariology, which involves the little considered, general modification of the theory based on the thought of St. Leo the Great. This current theory considers the change that took place in the term "Bogarodzica" to "Bogurodzica" [Mother of God] in the Polish song "Bogurodzica," which presents the "birth of Jesus unto God," His "consubstantiation" with the God-in Christ as God. The Father accomplishes this through the Holy Spirit by allowing Mary ("Daughter of God") to take part on the level of Jesus' humanity in His eternal act of bearing the Son. Ultimately, the Theotokos remains an unfathomable redemptive mystery. ${ }^{31}$

$29 \quad$ See C.S. Bartnik, Matka Boża, pg. 160.

$30 \quad$ See Ibid, pgs. 161.

31 See Ibid. In his text, Bartnik cites the first example of an attempt to express this idea: "Virgin, Mother of God, God-famed Mary! / Ask Thy Son, our Lord, Godnamed Mary, / To have mercy upon us and hand it over to us! / Kyrie eleison! // 


\section{Mother of the Communion of God and Men through Jesus Christ}

If man's $\sin$ is considered a rupture of the communion that God intended, then, "in the Most Holy Trinity's redemptive plan, the mystery of the Incarnation is the superabundant fulfillment of the promise that God made to men after original sin, the consequences of which burden all of human history on the earth (see Genesis $3: 15$ ). Thus, the Son-the 'descendant of the woman' who 'crushes the serpent's head'-came to earth." 32 Mary's faith-filled response to God's call, Her direct cooperation in the Incarnation, and Her willingness to put Herself at God's disposal, made it possible for Her to be the Mother of the Son of God and participate in the Incarnation. It also completely changed the redemptive situation of all people. Mary's motherhood was not a "private" relationship to the Son. Christ's uniqueness does not diminish a human person's being for others and with others in relation to God, who can also mediate God to others in communion with Christ in various ways. If this applies to all people, it applies all the more to Mary, who played a unique role in the Incarnation, and this role is both inalienable and unsurpassible. ${ }^{33}$

According to Galatians 4:4, Christ's birth of a woman is His kenosis - the Son of God's abasement and "humility" as well as the beginning of the era of redemption in the history of salvation: " "In Mary's place and space, the symphony of heaven and earth began (see Eph

Son of God, for Thy Baptist's sake, Hear the voices, fulfill the pleas we make! / Listen to the prayer we say, / For what we ask, give us today: / Life on earth free of vice; / After life: paradise! / Kyrie eleison!" (Bogiem stawiena Maryja. Antologia polskiej poezji maryjnej, Lublin 2000, pg. 7).

John Paul II, RM 11.

See G. Greshake, pg. 102n.

See C.S. Bartnik, Matka Boża, pg. 63: "The fact [that Christ] was born of a woman is as true as the fact that He redeemed man, or liberated him from 'bondage to the elements of nature' and from 'bondage under the Law.' The first two eras, including Judaism, became anachronistic (see Matthew). In one respect, [Jesus] had to free [man]: to redeem those who were 'in bondage under the Law' (Gal 4:5). 'The fullness of time' occurs only in the third age, during which a believer 'is no longer a slave, but a child, and if a child then also an heir through God' (v. 7). 'As proof that you are children, God sent the spirit of his Son into our hearts, crying out, 'Abba, Father!' (v. 6). Because [Christ] was 'born of a Woman,' man inherits the entire 'new world,' the new Eden that God prepared for him as his adopted and redeemed son. Because of this event, man receives a new existence free from elements, free from the temporality of the Law, free from sin, and full of God. Thanks to this Woman, the entire world can now call out to God "Abba, Father, Dad! This matter is so rich that it is difficult to describe it." 
1:10)." ${ }^{35}$ The reference to the woman from whom the Son was born, which moderately emphasizes the He belongs to the human world that awaits Him, "simply situates the woman as closely as possible to the eschatological fulfillment as a being that is closest to the heart of this mystery, the 'eschatological center' of history" 36 and openness to Her paradoxical motherhood. St. Paul begins to link Mariology with Christology by acknowledging Mary's motherhood and providing the first reflection that is rich in content and historico-redemptive reflection on its meaning. ${ }^{37}$ The Marian aspect "and we saw his glory" (John 1:14) speaks not only of the incarnate motherhood, ${ }^{38}$ but also the realization of the history of salvation and the paschal motherhood. " ${ }^{39}$ "The person of Mary, who enjoys complete interior communion with God, becomes a redemptive fire for all human nature and for others' personal cooperation with the grace of redemption." ${ }^{40}$ Mary is the "rainbow of divine forgiveness that extends over the entire world and the history of each person. This rainbow is the rainbow of the individual and universal covenant (see Gen 9:13-16)." ${ }^{41}$

In Redemptoris Mater, John Paul II wrote that the word "fullness" means the moment fixed from all eternity when the Father sent his Son

the blessed moment when the Word that 'was with God...became flesh and dwelt among us' (Jn. 1:1, 14), and made himself our brother [...] when the Holy Spirit, who had already infused the fullness of grace into

Ibid, pg. 158.

B. Forte, pg. 51 .

Ibid, pg. 52n.

Bartnik writes the following about John Paul II's Mariology: "Mary gives birth to the Word of God as human. She gives birth through Her 'I,' soul, thought, will, love, consent, Her fiat, and faith. She also gives birth biologically and gives Christ real body and blood [...]. Her entire person comes forth in giving birth, becoming a Mother, along with the earthly beginning of Jesus the Son of God. In this way, She mysteriously participates in the Father's bringing forth the Word of God. In the dogma of the incarnation, in this 'fullness of times,' in reference to the creation of the world, Mary became fully Herself [...]. Jesus Christ, on the other hand, became Himself primarily through the incarnation: His conception and birth. Biological motherhood involves a kind of personal motherhood. Mary shapes the psyche of Jesus, brings Him up, introduces Him to life and work, prepares the human part of Him to encounter the mystery of the Father, and instills in Him the personal structure of Advent [...]. Here too, the interior history of Jesus and Mary is intertwined" (Matka Boża, pg. 260).

See Ibid, pg. $94 \mathrm{n}$.

Ibid, pg. 135.

Ibid, pg.158. "She gave birth to [...] a new era, a new history; and She became a 'grassroots' sacrament of the earth" (por. Ibid, pg. 282). 
Mary of Nazareth, formed in Her virginal womb the human nature of Christ [and ...] when, with the entrance of the eternal into time, time itself is redeemed, and being filled with the mystery of Christ becomes definitively 'salvation time.' Finally, this 'fullness' designates the hidden beginning of the Church's journey. In the liturgy the Church salutes Mary of Nazareth as the Church's own beginning, for in the event of the Immaculate Conception the Church sees projected, and anticipated in Her most noble member, the saving grace of Easter. And above all, in the Incarnation she encounters Christ and Mary indissolubly joined: he who is the Church's Lord and Head and she who, uttering the first fiat of the New Covenant, prefigures the Church's condition as spouse and mother. ${ }^{42}$

The description of the Wedding at Cana $(2: 2,1-12)$ is an ecstatic messianic vision concerning the economy of grace-a vision in which Jesus, as the Spouse, opens wide the doors to the messianic kingdom and to heaven and invites everyone to the festivities. "[...] and the mother of Jesus was there (v.1) —as the main representative of Israel and humanity, and, therefore, in a certain sense as a spouse [...] Cana had to be the fulfillment and infinite transgression of the covenant entered into on Mount Sinai. [...] Christ, who had begun his public ministry to announce the Kingdom of God embodies a new marriage with humanity_a New Covenant—and fulfills Yahweh's former promise by establishing a "family of God and his people" (Emmanuel)..." 43 "Even though Jesus' reply to His mother sounds like a refusal (especially if we consider the blunt statement 'My hour has not yet come' rather than the question), Mary nevertheless turns to the servants and says to them: 'Do whatever he tells you' (Jn. 2:5)." ${ }^{4}$

42 John Paul II, RM 1.

43 C.S. Bartnik, Matka Boża, pg. 95. Por. Ibid, pgs. 95-97.

44 See John Paul II, RM: "It is certain that that event already quite clearly outlines the new dimension, the new meaning of Mary's motherhood. Her motherhood has a significance that is not exclusively contained in the words of Jesus and in the various episodes reported by the Synoptics (Lk. 11:27-28; 8:19-21; Mt. 12:46-50; Mk. 3:31-35). In these texts Jesus means above all to contrast the motherhood resulting from the fact of birth with what this 'motherhood' (and also 'brotherhood') is to be in the dimension of the Kingdom of God, in the salvific radius of God's fatherhood. In John's text on the other hand, the description of the Cana event outlines what is actually manifested as a new kind of motherhood according to the spirit and not just according to the flesh, that is to say Mary's solicitude for human beings, Her coming to them in the wide variety of their wants and needs. At Cana in Galilee there is shown only one concrete aspect of human need, apparently a small one of little importance ('They have no wine'). But it has a symbolic value: this coming to the aid of human needs means, at the same time, bringing those needs within the radius of Christ's messianic 
In Redemptoris Mater, John Paul II adds that another passage from the same Gospel confirms Mary's motherhood in the salvific economy of grace during the climactic moment of Christ's sacrifice on the Cross (John 10:25-27). In this event, one can clearly see the Son's particular care for His Mother, but the "testament from the cross" says even more. Jesus highlights and confirms the new bond between "Mother" and "Son." The Mother of Christ is given as a Mother to all people. The Second Vatican Council did not hesitate calling Mary the Mother of Christ and the Mother of Humanity, since Jesus told Her: "Woman, behold your Son." This phrase speaks more deeply about the mystery of Mary and Her particular "place" in the economy of salvation. ${ }^{45}$ Pope John Paul II wrote: "the motherhood of her who bore Christ finds a 'new' continuation in the Church and through the Church, symbolized and represented by John. In this way, she who as the one 'full of grace' was brought into the mystery of Christ in order to be his Mother and, thus, the Holy Mother of God through the Church, remains in this mystery as the "woman" spoken of [at the beginning of] the Book of Genesis (3:15) and at the end of salvation history in the Book of Revelation (12:1). In accordance with the eternal plan of Providence, Mary's divine motherhood is to be poured out upon the Church, as indicated by Tradition, according to which Mary's 'motherhood' of the Church reflects and extends how she is mother of the Son of God." 46

mission and salvific power. Thus there is a mediation: Mary places herself between Her Son and mankind in the reality of their wants, needs and sufferings. She puts herself 'in the middle,' that is to say She acts as a mediatrix not as an outsider, but in Her position as mother. She knows that as such She can point out to Her Son the needs of mankind, and in fact, She 'has the right' to do so. Her mediation is thus in the nature of intercession: Mary 'intercedes' for mankind. And that is not all. As a mother She also wishes the messianic power of Her Son to be manifested, that salvific power of his which is meant to help man in his misfortunes, to free him from the evil which in various forms and degrees weighs heavily upon his life. [...] Another essential element of Mary's maternal task is found in Her words to the servants: 'Do whatever he tells you.' The Mother of Christ presents herself as the spokeswoman of Her Son's will, pointing out those things which must be done so that the salvific power of the Messiah may be manifested" (21).

See Ibid, no. 23n.

Ibid, no. 24. 


\section{MATKA KOMUNII WCIELENIA}

Maryja jest Matką Wcielonego Syna Bożego, który stał się komunią Bóstwa i człowieczeństwa. Dlatego misterium macierzyństwa Maryi ma swoje odniesienia trynitarne. Jako umiłowana Córa Ojca i Oblubienica Ducha Świętego dała ludzką naturę Synowi Bożemu. Przez swojego Syna - Jezusa Chrystusa - stała się także Matką komunii Boga i ludzi.

Słowa kluczowe: Trójca Święta, Maryja, Wcielenie, Matka, komunia.

\section{Bibliography:}

1. Adamiak E., Traktat o Maryi, in Dogmatyka, (ed.) E. Adamiak, A. Czaja, J. Majewski, Warsaw 2006, pgs. 15-287.

2. Bartnik C.S., Dogmatyka katolicka, Vol. II, Lublin 2003.

3. Bartnik C.S., Matka Boża, Lublin 2012.

4. Bogiem stawiena Maryja. Antologia polskiej poezji maryjnej, Fundacja Servire Veritati, Lublin 2000.

5. Forte B., Maryja, Ikona Tajemnicy. Zarys mariologii symboliczno-narracyjnej, trans. B. Widła, Warsaw 1999.

6. Greshake G., Maria-Ecclesia. Perspektiven einer marianisch grundierten Theologie und Kirchenpraxis, Regensburg 2014.

7. Jagodziński M., Węzłowe zagadnienia chrystologii komunijnej, Radom 2013.

8. John Paul II, Encyclical: Redemptoris Mater (1987).

9. Catechism of the Catholic Church (2003).

10. Laurentin R., Matka Pana. Traktat mariologiczny, trans. R. Siemieńska, Częstochowa 1989.

11. Ratzinger J., "I za sprawa Ducha Świętego przyjąt ciato z Dziewicy Maryi," in J. Ratzinger, H.U. von Balthasar, Maryja $w$ tajemnicy Kościoła, trans. W. Szymona, Cracow 2007, pgs. 71-84.

12. Second Vatican Council, Dogmatic Constitution on the Church in the Modern World: Lumen Gentium (1964). 